IZA DP No. 8790

Innovation and SMEs Patent Propensity in Korea

Junghee Han

Almas Heshmati

January 2015

Forschungsinstitut zur Zukunft der Arbeit Institute for the Study of Labor 


\title{
Innovation and SMEs Patent Propensity in Korea
}

\author{
Junghee Han \\ Chonnam National University \\ Almas Heshmati \\ Jönköping International Business School, \\ Sogang University and IZA
}

\section{Discussion Paper No. 8790 January 2015}

\author{
IZA \\ P.O. Box 7240 \\ 53072 Bonn \\ Germany \\ Phone: +49-228-3894-0 \\ Fax: +49-228-3894-180 \\ E-mail: iza@iza.org
}

Any opinions expressed here are those of the author(s) and not those of IZA. Research published in this series may include views on policy, but the institute itself takes no institutional policy positions. The IZA research network is committed to the IZA Guiding Principles of Research Integrity.

The Institute for the Study of Labor (IZA) in Bonn is a local and virtual international research center and a place of communication between science, politics and business. IZA is an independent nonprofit organization supported by Deutsche Post Foundation. The center is associated with the University of Bonn and offers a stimulating research environment through its international network, workshops and conferences, data service, project support, research visits and doctoral program. IZA engages in (i) original and internationally competitive research in all fields of labor economics, (ii) development of policy concepts, and (iii) dissemination of research results and concepts to the interested public.

IZA Discussion Papers often represent preliminary work and are circulated to encourage discussion. Citation of such a paper should account for its provisional character. A revised version may be available directly from the author. 
IZA Discussion Paper No. 8790

January 2015

\section{ABSTRACT}

\section{Innovation and SMEs Patent Propensity in Korea}

This paper analyzes the patent propensity as an outcome of innovative activities of regional SMEs. To achieve the aims, we apply robust regression analysis to estimate the models to test 5 research hypotheses using 263 firm level data located at Gwangju region in Korea. Our empirical results show that a firm's industry characteristics, such as machinery and automotive parts industry, is negatively related with propensity to patent innovation. Also, unlike expectations, the InnoBiz firms designated as innovative SMEs by the government are not performing differently than general firms. Only the CEO's academic credentials are positively related with propensity to patent. From the findings, we can conclude that patenting propensity is not directly related with a firm's characteristics but mainly to CEO's managerial strategy. Also, we cannot find evidence for policy effectiveness from public support given to InnoBiz firms as part of the state policy to nurture photonic industry to boost regional economic development. Given the lack of strong policy effects, a new industry policy should be considered to actively promote SMEs innovativeness.

JEL Classification: C51, D22, O31, O32

Keywords: $\quad$ patent propensity, photonic industry, SMEs growth, R\&D, innovation, InnoBiz, Korea

Corresponding author:

Almas Heshmati

Department of Economics

Sogang University

Room K526, 35 Baekbeom-Ro, Mapo-Gu

Seoul 121-742

Korea

E-mail: heshmati@sogang.ac.kr 


\section{Introduction}

Patenting is the representative proxy of innovation outputs and as such, an important managerial strategic activity. However, it is not the only mean for appropriation, i.e. for capturing returns from R\&D investments (Teece, 1986; Levin et al., 1987). For example, instead of patenting, firms can also choose to protect their innovations by secrecy, sales or service efforts, lead time creation, and/or low-cost production (e.g. Levin et al., 1987). Patents can contribute to the performance of firms through improvements in the rate of innovation, productivity, and market value (Bloom and Van Reenen, 2002; Griliches, 1981; 1990; Hall, 2004). Patenting strategy plays an important role in firm growth. Regardless of firm sizes, innovation is crucial to securing constant growth for all corporations. Both firm survival and firm growth have been dealt with equally by researchers (Geroski, 1995; Sutton, 1997). For small and medium-sized enterprises (SMEs), the growth of firms is critical to ensuring survival (Lotti et al., 2009). A firm's constant growth is homework for all managers. A variety of managerial activities exist for this (e.g., searching for new idea, enlarging the network activities). Innovation is at core of contemporary business, and therefore, innovation investments are central to the competitiveness of firms. Patent as innovation outputs can be used as a tool not only for protection in innovation management but also for incentives creation, collaboration, negotiation, licensing, etc. (Scherer, 1983; Arundel and Kabla, 1998; Granstrand, 1999; Nicolas, 2011; Han et al., 2011). Patents were used to attracting customers and venture capital, which is of utmost importance for the survival and growth of innovative firms. Thus, patenting plays an important role even in firms where the protection functions secondary.

The previous literatures, in particular, studies of the relationship between research and development (R\&D) activities and SMEs growth are especially valuable at the regional level. $R \& D$ activities have various facets. $R \& D$ activities enable firm to diversify their activities such as forming strategic cooperation network with other firms (Roger, 2004; Han et al., 2008), absorbing knowledge created from the relationships formed with agents, as well as maximizing their capacity to use that knowledge to increase their performance (Cohen and Levinthal, 1990; Han et al., 2008). R\&D activities vary greatly according to the industries. So, patent propensity could also differ according to the industries along with other factors. The objective of this study is to empirically find whether industry characteristics, firm characteristics, InnoBiz (innovative firm certified by the government), firm age, research division, and CEO's academic credentials affect the firms' patent propensity. The naming of InnoBiz originates from a compound with 'Innovation' and 'Business', which means the Act on Promotion of Technology Innovation based on technical excellence like High-Technology firm system designated by Small Business Innovation Research (SBIR) in the United States. This paper will shed new light on ways of innovation polices aimed to influence firm's growth in Korea.

In order to achieve the research goal, we consider a sample of 263 SME firms from the manufacturing industries consisting of high-tech as well as non-high-tech firms operating in Gwangu, South Korea. We believe SMEs located in Gwangu have certain weakness in their $R \& D$ activities due to the uneven industrial development policy implemented by Gwangu region, which is the lowest among eight main regions in Korea. The sample of firms included by the government designated innovative firms in Guangju between 2010 and 2013. The data is collected from several institutions (i.e., 
SMEs center, Association of Managerial Foundation in Gwangju, and Cooperation of InnoBiz). According to the findings, CEO's academic credentials are the primary factor positively associated with the patent propensity. Surprisingly, with regard to the industry characteristics, both automotive parts industry and electronics and electricity industry are less likely to patent innovations; they are rather interested in cost comparativeness. Lack of difference in innovation activities and outcome between InnoBiz firms and general SMEs is highly unlikely. Another factor of importance is the number of researchers that has positive effect on the patent propensity.

The remainder of the study is structured as follows. Section 2 presents the literature review and hypothesis investigated. Section 3 presents data sets, variables, and estimation methodology. Section 4 presents the results and discusses them. Finally, Section 5 presents conclusions and implications.

\section{Literature Review and Hypothesis}

Innovation is at core of competitiveness of firms. Investment in R\&D within limited resources is a very important managerial strategy because it is difficult for innovators to exclude others from benefiting the developed knowledge resources. In spite of it, we have questions as to why firms have patenting strategy. Various previous studies have tried to answer those questions. The concept of patent propensity has different meaning. Scherer (1983) emphasizes on patent for $R \& D$ ratio as an outcome, while Mansfield (1986) and Arundel and Kabla (1998) define patent propensity as probability to patent a patentable invention. Previous studies on patent propensity show the patent propensity differs among industries (Scherer, 1983; Mansfield, 1986).

Important reasons for firms to patent include: to prevent imitation, to avoid trials, to reach strong positions in negotiations (Arundel et al., 1998; Duguet and Kabla, 1998; Granstrand, 1999; Nicolas, 2011; Han et al., 2011), to block other firms' R\&D and patenting efforts (Han et al., 2011; Thumm, 2004), to enhance the firm's reputation (Thumm, 2004), and more so for small firms than for large ones according to the previous studies (Cohen et al., 2000). Hall and Ziedonis (2001) found that the value of patents as 'bargaining chips' in negotiations had increased. Worth noting, moreover, is that standard-setting motives for patenting have been of increasing importance, especially within the telecommunications industry (Granstrand, 1998). Patenting is not only a means for appropriation, i.e. for capturing returns from R\&D investments (Teece, 1986). According to Hsu and Ziedonis' (2008) findings, patent filings have economically large effect on investor estimates of start-up values. In this study, they also show that the effect of patenting on start-up valuation is more pronounced in earlier financing rounds, consistent with the view that patents provide a mechanism for overcoming early-stage disclosure issues in the market.

\subsection{Patent propensity and innovative firms}

Patent-based indicators are increasingly used to assessing the rate of innovative activities. Of course, it is well known that not all inventions are patentable and that not all patentable inventions are actually patented. At the firm level, an increasing number of empirical works have studied which firm characteristics increase the likelihood to innovate and enhance productivity of firms (Heger and Zaby, 2012). As mentioned 
earlier, patent propensity varies across industries. Mansfied (1986) shows differences of patent propensity according to the industry by conducting survey of 100 United Stated manufacturing firms, (i.e., ranging from $50 \%$ in primary metals to $86 \%$ in petroleum and machinery).

Studies of European firms have confirmed such industry variations and show that patent propensity is lower for process innovations than for product innovations (Arundel and Kabla, 1998; Brouwer and Kleinknecht, 1999). This means that a common view is that patent protection is in general more effective for product innovation than process invention since the latter is more difficult to reverse-engineer (Grandstand, 1999). Bouwer and Kleinknecht (1999) show that patent propensity is higher among R\&D centered firms by doing survey of 1,300 Dutch manufacturing firms. According to Scherer (1983)' findings, patent numbers correlate with R\&D linearly. In other words, the more we invest in $R \& D$, the more patents is registered. Also, R\&D expenditure contributes to increased diversification of activities, making SMEs more competitive (Rogers, 2004 ).

Heger and Zaby (2012) find that a firm's propensity to patent increases in its technological lead in industries in which reverse engineering is relatively easy. That is, if a firm is highly successful but threatened by low cost imitation, it is more likely to patent since it has more to lose. Nicholas (2011) finds if $R \& D$ facilities are geographically located close to the firm, a firm is likely to have higher patent propensity. Gwangju city has tried to attract the Public R\&D facilities to be located in the region since 2001. As a result, there are many $R \& D$ facilities including Korea Photonics institutes in Gwangju. InnoBiz firms are recognized by the government as innovative in Korea, so the preceding literature review suggests the following hypothesis:

Hypothesis 1: InnoBiz (designated innovative) firms are more creative in patenting than general SMEs.

\subsection{R\&D intensity and $R \& D$ division}

One of the often measured types of innovation activities is R\&D intensity. Scherer (1983) defined R\&D intensity as patent per R\&D investment ratio. Alike Scherer's definition, commonly, $R \& D$ intensity has used investment for research and development per turnover or total sale. In order to effectively fulfill the innovation output, inter or intra organizational structure and relationships is important (Eisingerich et al., 2009). The previous literature shows that in order to boost firm growth, a firm has an internal good organizational such as a research division (Eisingerich et al., 2009). The function of research division varies and includes: suitable strategies for diversifying activities for firm survival (Griliches, 1990), strategic cooperation between firms with respect to R\&D projects (Williams and Lee, 2009), greater external knowledge absorption (Cohen and Levinthal, 1990), and the greater capacity to implement complementary strategies with other firms or R\&D institutions (Arora and Gambardella, 1990).

Lerner and Wulff (2007) find that in firms, centralized R\&D division and long-term incentives for managers go together with more heavily cited and original patents, suggesting that centralized $R \& D$ is more conducive to encouraging original research. 
Argyre and Silverman (2004) found that a centralized R\&D division will generate innovations that have a larger and broader impact on subsequent technological evolution compared to decentralized research. In the case of innovative SMEs like InnoBiz in Korea, establishing the research division is mandatory to obtain certificate for InnoBiz. In capturing the InnoBiz effect, we formulate the following hypothesis:

Hypothesis 2: Research fund and research division are of greater importance in patent propensity in terms of the performance of SMEs.

\subsection{Firm size and age}

Various previous studies explain a positive relationship between the firm size and patent propensity. Mansfied (1986) shows that patent propensity increases with firm size through the survey of 100 U.S firms. In another study, according to the findings from the empirical study on Europe's 604 largest industrial firms, patent propensity increases with the firm size (Arundel and Kabla, 1998). Nicholas (2011) shows that patent propensity differs according to the industry characteristics, firm size, and geographic location of R\&D facilities. Also, by doing survey among 2,777 innovative firms in the 1920s and 1930s, Nicholas (2011) emphasizes that the determinant of patent propensity depends on whether R\&D facilities exist or not. Chabchoub and Niosi (2005) find that by using financial, geographic and patent data, determinant of propensity to patent is closely related to the firm size.

Many firm level studies investigate firm growth. Several studies (e.g., Lotti et al., 2009) have concluded that smaller firms grow faster than larger ones. In the context of SMEs, larger, older firms will be expected to grow less than smaller, younger ones. Therefore, we can expect the relationships between size and growth and between age and growth to be negative. Small or young firm tend to have higher patent per R\&D ratios than large ones (Bound et al., 1984; Granstrand, 1988). One part of the explanation could be that small firms have higher R\&D yields but lower patent propensities than large firms. Another part of the explanation could be that innovation activities in large firms are underestimated when measured with patent statistics while innovation activities in small firms are underestimated when measured by R\&D statistics (Pavitt, 1982). Based on the above considerations, we formulate the following hypothesis:

Hypothesis 3: Older firms are more likely to have patent propensity than younger firms.

\subsection{Characteristics of SMEs}

Hoffman et al. (1998) argue based on a literature review that the innovative activities of SMEs are more likely to involve product than process innovation, more likely to focus on niche rather than mass markets, and more likely to involve linkages to external resource. Small firms are also more likely to patent, to license, or to convince investors and banks of the value of their inventions (Granstrand, 1988; Rassenfosse, 2012).

The innovating small firms are typically specialized in their technological strategies, concentrating on product innovation in specific producers' goods, such as machine tools, scientific instruments, specialized chemicals, or software. Their key strategic strengths are the ability to match technology with specific customer requirements. The key strategic tasks are finding and maintaining a stable product niche, and benefiting 
systematically from user experience. Mansfield (1986) found that patent propensity varies over firm's characteristics, e.g., industries, ranging from $50 \%$ in primary metals to $86 \%$ in petroleum and machinery. The patentable invention per $\mathrm{R} \& \mathrm{D}$ ratio varies over industries. Patent propensity did not change significantly between the late 1960s and early 1980s. Patent propensity increases with the firm size. Arundel and Kabla (1998) showed that through survey of Europe's 604 Industrial firms, propensity to patent also varies over industries, e.g., for product innovations ranging from $8.1 \%$ in textiles to $79.2 \%$ in pharmaceuticals. Patent propensity is higher for product innovations (average 35.9\%) than process innovations (average 24.8\%). Patent propensity increases with the firm size. $R \& D$ intensity does not affect patent propensity.

Nicholas (2011) showed that firms of the 1920s and 1930s were more likely to patent than modern R\&D firms. Industry, firm size, and geographic location of R\&D facilities are important determinants of the propensity to file for at least one patent. The preceding literature review suggests the following hypothesis:

Hypothesis 4: The firm's characteristics are related with innovative output measured as patent.

\subsection{CEO's academic career}

CEO's ability is the composition of observable and quantifiable characteristics such as education and work experience, as well as unobservable and potentially nonquantifiable characteristics such as leadership and team-building skills. Managers make a number of strategic choices when trying to capture returns from innovation investments, including what appropriation strategy to use and whether or not to patent. These are among the strategic choices that depend on the firm size among other things. Interestingly, Kim and Han (2014) show that CEO's academic credentials are not related with firm performance in Korea. However, age is a related factor; namely, a young CEO is likely to have a higher performance than their older CEO counterparts; a young CEO is likely to have better academic credentials, (e.g., in Korea, more than $90 \%$ of CEOs of venture firms have a Ph.D. degree) than their older counterparts.

CEO's education potentially impacts his ability in three mutually non-exclusive ways. First, education could potentially contribute to the CEO's knowledge, perspective, and ability to understand technical and abstract concepts. Second, a higher level of education could be a sign of the CEO's intellectual ability to persevere on challenging intellectual activities. Finally, the social networks acquired in college and graduate schools can be quite helpful professionally in the future innovative ventures. As discussed above, however, CEO's education is just one of the determinants of CEO's ability. Hence, it is a priori unclear how much impact CEO's education has on firm performance (Bhagat et al., 2010). The concept of entrepreneurship is neither entirely clear in the literature nor commonly agreed upon (e.g. Gartner, 1990; Covin and Slevin, 1991; Dean and Meyer, 1996) despite its long history arguably dating back to the $17^{\text {th }}$ century. However, here, the entrepreneurial SMEs are defined as SMEs that base their businesses on new or improved technologies and/or that are newly established or with new or improved means of commercialization and growth. Thus, the preceding literature review suggests the following hypothesis:

Hypothesis 5: CEO's academic career/credentials is (are) positively related with patent 
as innovation output

\subsection{Other control variables}

We use several control variables in our analyses whose choices are guided by the previous literature findings. For instance, the number of researchers is controlled in this paper. If a firm has research division like a research center, the number of researchers affects the patent activities already. Namely, a researcher still works primarily in a research role, rather than product development or marketing (Lowe, 2001). Thus, given our sample, the number of researchers is to be controlled.

\section{Data and Research Methodology}

As described above, the objective of this paper is to find the relationship between innovative firm and patent propensity. This is against the background that InnoBiz and entrepreneurship SMEs are expected to have a higher innovative propensity than general SMEs in Gwangju. The assembled dataset was composed of 15 variables that could be related to a firm's characteristics including financial performance over the last 3 years. Taking into consideration the regional industry conditions, the data collected from the automotive part industry \& machinery, electronic \& electricity industry, and photonic industry is utilized for the purpose. It covers the period from 2011 to 2013, accounting for representativeness of the firms.

The data set is unique. In particular, in order to test the stated research hypothesis, this study draws on representativeness of each firm. Patent data was collected from the Korea Institute of Patent Information (KIPI), an affiliated public institute of the Korean Intellectual Property Office (KIPO). KIPI has been designated as a specialized institute providing information on industrial property rights to build an information infrastructure for Korea's intellectual property. Independent variables (e.g., R\&D intensity, firm age, CEO's academic degree, and the number of researcher) were obtained from the Korean Investment Service, a Moody's affiliate, and the Korean Small and Medium Business Administration (SMBA). SMBA has supported Korea's SME-led innovation as a dynamo of the national economy. Namely, SMBA's primary mission has been to foster challenging and innovative SMEs to maximize the growth potential of Korea. In particular, SMBA's regional branch office keeps subtle data, for example, CEOs' career history, where the employees are coming from, financial states, main product lines, etc. We utilize this data for analysis of innovative outputs as a means of data complementary.

The data composed of 263 firms was collected from official databases and covers the period from 2010 to 2013. The sample is suitable for studying the research goal since it is well known for its high share of entrepreneurial and manufacturing SMEs. Concerning the firm size, SMBA definition based on fewer than 350 employees was used. The structure of employees was composed from 1 to 303. The mean employee value is 36. Considering InnoBiz, 112 firms (43\%) are certificated. The frequency distribution of the industry categorical variables is 151 (58\%), 51 (19\%) and 61 firms (23\%) for automotive part and machinery industry, electronic and electricity industry, and photonic industry respectively. The industry frequency distribution (Figure 1) shows that the regional industry characteristic that Gwangju has the biggest automotive 
firm, KIA. So, the first tier and second tier of KIA automotive company are more than $50 \%$ of the regional firms. Figure 1 shows that the ratio of industry is balanced in representing the regional firms. As a global car maker, KIA has been pivotal in its contribution to the development of regional economy and growth. There are so many automotive relative SME firms in the line of value chain. Traditionally, electronic and electricity industry is the second biggest contributor to the regional economy in GwangJu.

Figure 1. Frequency distribution of firms by industry classification

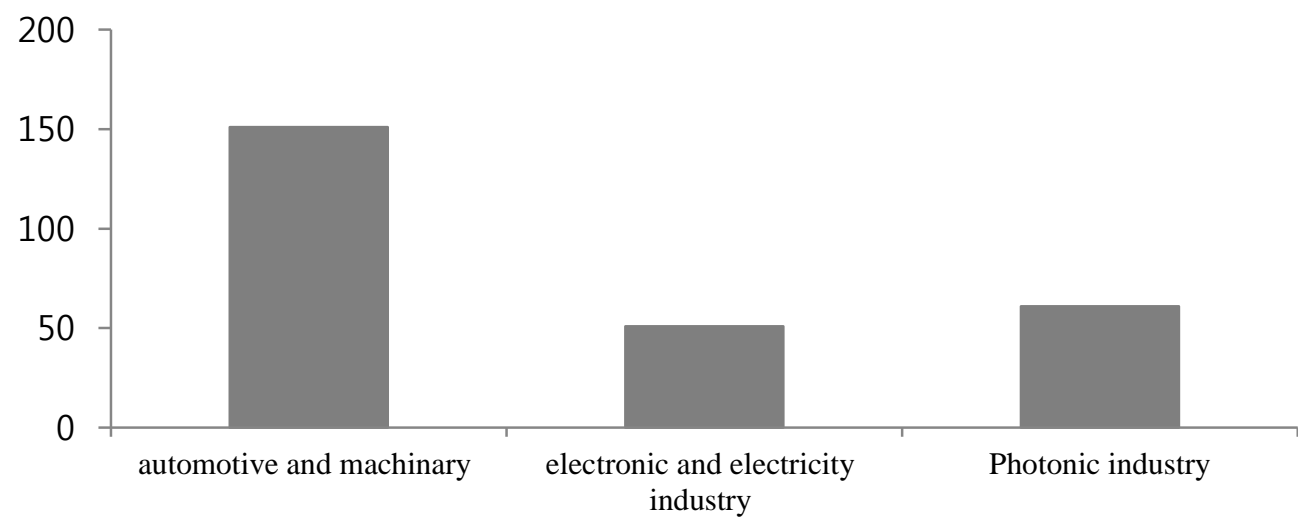

From the raw data, we find that the ratio of InnoBiz (43\%) is relatively high considering the history of implementing the InnoBiz certificated firms first in 2001. We can assume that young firms with less than 10 years of operation are mainly InnoBiz. The data also informs that young firms could be more innovative than others. Considering the number of patent for each firm in the last 3 years, it can be found that young firms have higher number of patents than older firms. Namely, InnoBiz firms are likely to be more engaged in innovative activity and have a higher success rate in generation of patents. In its 2001 regional economic policy, the central government designated Gwangju as a photonic industry complex area in order to boost the regional SMEs. The Korea Association for Photonics Industry Development (KAPID) was established with the purpose of developing South Korea's photonics industry and promoting and expanding relevant businesses. The Korean government has selected the photonics industry as one of its high-tech industries for the 21st century and has established plans for substantial investment and systematic promotion of this industry. As part of the government's strong support, the KAPID was set up as a major civil organization to promote the photonics industry. The photonics industry is a high valueadded cutting-edge industry based on new technologies.

As mentioned above, in accordance with the government's plan to promote the photonics industry, the nation's largest photonics-oriented industrial complex was established in Gwangju. Table 1 shows that the number of firms with a research division are relatively few at 84 (32\% out of 263), considering the number of InnoBiz which is 112 firms. From the dataset, we can assume that some of the InnoBiz firms do not even have a research division. Certainly, just because a firm has a research division, it does not mean that it is an innovative firm. The average age of the firm is 12 years, which is relatively young firm. With regard to the CEO's academic credentials, only a few have Ph.D. For the attributes of photonic industry, cutting edge technology and pure science knowledge are required. It is expected that the higher the CEO's academic 
credentials, such as Ph.D., the greater the likelihood of their innovation success. However, only 28 CEOs have Ph.D. Interestingly, the number of firms with no patents is more than half of the observations. Many firms have not been engaged in patent as an important innovative output from the data description.

\section{Insert Table 1 here}

Table 2 reports the summary statistics of the data. The correlation matrix of dependent and independent variables (Appendix A) showed that the correlation between the independent variables is not high, suggesting that multicollinearity and confounded effects are not a serious problem.

\section{Insert Table 2 here}

Based on the findings from the review of literature on innovation activities and innovative outcomes (patents) of SMEs and the availability of representative data, we have specified a model of patent propensity as follows:

$$
\begin{gathered}
\text { Patents }_{\mathrm{i}}=\beta_{0}+\beta_{1} \text { ResFun }_{i}+\beta_{2} \text { Age }_{i}+\beta_{3} \text { ResDiv }_{i}+\beta_{4} \text { Researcher }_{i}+\beta_{5} \text { InnoBiz }_{i} \\
+\beta_{6} \text { IndCode }_{i}+\beta_{7} \text { CEOdeg }_{i}+\varepsilon_{i}
\end{gathered}
$$

where the subscript $i$ indicates firm, the ResFun, Age, ResDiv, Researcher, InnoBiz, IndCode, and CEOdeg are research fund, age of firm, research division, InnoBiz certified, industry code, and CEO degree, $\beta$ 's are the effects of explanatory variables on the number of patents, and $\varepsilon$ is an error term capturing the effects of left out variables, measurement error in patents, and random events. The IndCode and CEOdeg are categorical variables. For a matter of sensitivity analysis of the relationship between patent of explanatory variables, several models are estimated. Multivariate regression analysis is used for estimation using the OLS method with robust standard errors. The results are presented below.

\section{Results and Implications}

Patents are frequently considered to be an indicator for outputs of a research and development. This indicator may be considered as handy in valuing the output of research activities. However, there are some shortcomings to this indicator. For example, a company or an individual sometimes does not want to disclose the results of their research in order to preserve exclusive or monopoly rights to their invention or innovation.

In this paper, 5 research hypotheses are being tested. In order to elaborate the empirical findings, interviewing is also being utilized. Table 3 presents the empirical results from the estimation of the patent propensity model. We find that the first research hypothesis, (i.e., InnoBiz firm is more creative in patents than general SMEs) is statistically rejected. As we mentioned previously, InnoBiz firm was designated by the government among the general SMEs as innovative firms by screening firms by their innovative performance. This finding is unexpected, when taking into account the designation process. InnoBiz certificate is given by evaluating the innovative performances based on the Oslo manual with standardized list of indicators of innovation and innovativeness. So, once some SMEs have obtained InnoBiz certificate, these are considered as innovation-driven firms. Of course, innovation output can be measured 
by various aspects including patents and share of sales attributed to new products and processes. In light of the findings of Holgersson (2012)'s study, result of hypothesis 1 is somewhat understandable. Holgersson (2012) showed interesting results by analyzing the survey of patenting and entrepreneurship in the United States by summarizing the responses of 1,332 early-stage technology companies founded since 1998. According to the findings, the traditional theory that patents provide an incentive to invent is varied subtly. Surprisingly, startup executives' responses indicate that patents generally provide relatively weak incentives to conduct innovative activities.

Insert Table 3 here

Establishing internal research division is mandatory in Korea to obtain the InnoBiz certificate and to take advantage of public incentives provided. The previous research findings show that in order to boost firm growth, a firm needs to have good internal research organization and capacity including a research division (Eisingerich et al., 2009).

Hypothesis 2 (i.e., Research fund and research division is of greater importance in patent propensity in terms of the performance of SMEs.) is also statistically rejected with respect to research division. In other words, it can be assumed that research divisions within the firms may not pursue patenting but enhancing other performance activities, such as creating new product line designs and creating new marketing strategies. First, as mentioned above, the function of research division varies including: suitable strategies for diversifying activities for firm survival; strategic cooperation between firms with respect to R\&D projects; greater external knowledge absorption (Cohen and Levinthal, 1990), and greater capacity to implement complementary strategies with other firms or R\&D institutions (Arora and Gambardella, 1990). Second, it can be assumed that research divisions may not facilitate research and development, but may give priority to survival strategies like other management divisions. According to the interview from researchers, there are several reasons opting against patent protection: the technology not being patentable; the high costs associated with prosecuting and enforcing the patent; the perception that, with reverse engineering, that patents may afford relatively weak protection; and the fear of disclosure.

However, a somewhat expected result is that the research fund and the number of researchers used as control variable are positively related with patenting and are statistically significant.

Small firms or young firm tend to have higher patent per R\&D ratio than large ones (Bound et al., 1984; Granstrand, 1988). One part of the explanation could be that small firms have higher R\&D yields but lower patent propensities than large firms. Another explanation could be that innovation activities in large firms are underestimated when measured with patent statistics while those in small firms are underestimated when measured by R\&D statistics (Pavitt, 1982).

Hypothesis 3 (i.e., the older firm is likely to have a lower patent propensity than the young firm) is statistically insignificant and thereby rejected. Considering the data analysis, we expected this finding since more than $80 \%$ of younger firms (157 firms) that are less than 10 years have no patents. Even though young firms are more likely to invest in $\mathrm{R} \& \mathrm{D}$, the rejected hypothesis 3 may be explained by unmeasured variables such as external effects. Using the discussion with entrepreneur and researchers, most 
common reasons why startups choose not to patent their innovation included: not wanting to disclose the information; the cost of getting the patent, including the attorneys' fees; that competitors could have easily invented around the patent; that they believed trade secret was adequate protection; the cost of enforcing the patent, including actions in court; that they did not believe the technology was patentable; and that they had no need for legal protection. The literature reviewed showed that Mansfield (1986) found patent propensity to vary by firm's characteristics. The patentable invention per $R \& D$ ratio varied across industries.

Hypothesis 4 (i.e., firm's characteristics are related with patent) is negative and significant for both automotive \& machinery and electronic and electricity industries. Based on the discussion with entrepreneurs and researchers, it was found that regardless of firm's characteristics, the reason they do not want to patent is the cost of filing and the belief that the technology was not patentable. This finding shows that in comparison with other regional industry conditions of neighboring regions like Changwon, Gwangju is lagging behind. According to analysis of the raw data for automotive \& machinery, these firms origin was the automotive mold manufacture. Mold industry has been known as the representative industry in Gwangju. In general, what is important is not patenting but manufacturing with cost competitiveness in the mold industry. We found that core automotive \& machinery parts are brought from SMEs in the Changwon area instead of Gwangju. In order to improve the tier systems of automotive, InnoBiz firms are staring up recently with support from the local government. SMEs in electric and electricity in Gwangju show far fewer patents than those of SMEs in Changwon with regards to the number of patents in the last 3 years. However, it is interesting that SMEs among the electric and electricity firms are notably highly productive in patenting. Local government has focused on nurturing the household robot industry to the next generation of growth engine based on the existing infrastructure including the production technology as the biggest home appliance cluster in the country. In particular, in order to boost the household robot industry, a specialized such center was established in 2011.

Managers make a number of strategic choices when trying to capture returns from innovation investments, including what appropriation strategy to use and whether or not to patent, strategic choices that depend on the firm size among other things. CEO education potentially impacts the CEO's ability in three mutually non-exclusive ways. First, education could potentially contribute to the CEO's knowledge, perspective, and ability to understand technical and abstract concepts. Second, higher education could be a sign of the CEOs intellect and ability to persevere on challenging intellectual activities. Finally, the social networks acquired in college and graduate school can be quite helpful professionally in the future. As discussed above, however, CEO education is just one of the determinants of CEO's ability. Hence, it is a priori unclear how much impact CEO education has on firm performance (Bhagat et al., 2010).

Hypothesis 5 (i.e., CEO's academic career is related with patent) is statistically and positively significant for CEOs with Ph.D. degree but not below it. This finding has important implications. First, CEOs having a Ph.D. degree may be more innovative. In reviewing the previous studies, patents can contribute to the performance of firms through improvements in the rate of innovation, productivity, and market value (Griliches, 1981; Bloom and Van Reenen, 2002; Hall, 2004). On the other hand, CEO’s academic background is not related with firm performance in Korea (Kim and Han, 
2014). However, age is related in that younger CEOs are likely to perform better than older CEOs. Young CEOs likely to have higher academic degree (e.g., more that $90 \%$ CEO of Venture firms have Ph.D. in Korea) than their older counterparts. The reason for higher academic credentials in Gwangju is the presence of the phonemic industry. Photonics industry has the features and convergence with the existing industry, and is important as a basic industry with a very high scientific base.

Gwangju-Si has nurtured the photonics industry in the level of promoting the regional strategic industry since 2000 and established an international photonics industry cluster where industrial, academic, and research functions are integrated based on the hightech scientific industrial zone structure. Therefore, phonics related InnoBiz firms established by CEOs with a Ph.D. degree enhance the national photonics development technology infrastructure. As a result, the Advanced Photonics Research Institute (APRI) including the Korea Photonics Technology Institute (KPTI) was established. Based on the data, it is found that the percentage of CEOs with a Ph.D. degree is the highest in the photonic industry.

From the empirical results in this study, we note that the research fund per turnover, the number of the researchers and high caliber CEOs are positively related with patent production and statistically significant. However, InnoBiz certified firms and the firm's age are statistically insignificant. Regardless of the industry characteristics, patenting propensity is decreased.

\section{Final Remarks}

When exploring the patenting propensity in terms of innovation type, thus, process innovation and product innovation, we cannot find any difference with respect to patenting propensity. This result implies that regardless of the technology types, patenting propensity is decreased. Of course, patents do not have the same weights regarding their impact on commercialization by using their own technologies and information. However, trends in patenting are a clear indicator of the research activity, and therefore, they cannot be neglected.

Patent propensity is related to the underlying management decision of whether to apply for patent protection for an invention or not (Marcus, 2012). Empirical findings also reveal that CEO's academic career is positively related to the patent propensity.

Surprisingly, in this study, automotive parts industry and electronic and electricity industry are less likely to have a high patent propensity. According to the information gathered through personal interviews in SMEs, those reasons can be attributed to KIA, one of the car makers in Korea, and Samsung. A look at the automotive industry's characteristics reveals/shows that it has vertically integrated structure on the center of the assembler. If a small firm as the first and /or second tier of the assembler cooperates with a car maker, this firm should follow the car maker's requirements. Therefore, small firms appear not to implement their own innovation managerial strategies. Rather, they are likely to be subordinates of the carmaker. In order words, instead of using their own innovation strategy spontaneously, SMEs mainly focus on trying to read the car maker's requirements. So, small firms are primarily interested in enhancing their comparative cost advantage. Therefore, numerous SMEs are less likely to have a high 
patenting propensity. Another reason is that the assembler requires continuously producing the automotive parts for more than 10 years once SMEs start to make the automotive parts, regardless of the possibility of stops in assembling the car. Nevertheless, it is very hard to catch up with the development of new car models so that they should keep a line with the old products. Importantly, car makers do not like SMEs with patent propensity strategy, as indicated by the interview.

Samsung's home appliances factory is located in Gwangju. Numerous SMEs are linked to Samsung. However, following the pulling out of the appliance factory, SMEs collaborated with Samsung to change their product line since 2008. Thus, we cannot find any clustering effect from cooperative innovation from the empirical results. Gwangju is located in south of Seoul and has relatively few firms compared to other industrial cities in Korea. Expect for a large automotive firm, KIA, which is representative of the Korean automotive firms along with Hyundae, there are only a few firms. The central government has been providing support in order to ignite regional industry revitalization since the beginning of 2000. In Gwangju, the photonic industry is what is progressive. Thanks to the public policy support, the photonic industry has been fast growing since 2001. As of 2014, 364 firms are established and more than 8,000 new employment opportunities have been created over the last ten years. In that sense, those firms should be more innovative than other industry sectors. However, we cannot find evidence for higher patent propensity in the photonic industry. In addition, it is commonly known that the photonic industry is an innovative industry. So, there are many InnoBiz (innovation designated) firms in Gwangju compared with other regions in Korea. However, the findings did not reveal any significant patent propensity to serve as proxy of innovation activities even for the target InnoBiz firms at Gwangju.

Now, Korean SMEs account for 99\% of all corporations and 88\% of all employment. InnoBiz certificate system has aimed to accelerate the driving force of SMEs in Korea since 2001. By several supports of the innovative activities of the firms, performance should be enhanced as SMEs are in general a growth engine. Some policy implications must be drawn from the empirical results. In order to nurture SMEs, taking into consideration Korea's ecology industry systems, policy instrument touches the collaboration between large conglomerated firms and SMEs. In particular, in order to enhance the innovation of SMEs, the role of research division in the firm level should be reconsidered. Regardless of general SMEs or InnoBiz firms, we cannot find evidence of any effects on the patent propensity as innovation performance proxy from the empirical findings. With respect to the findings, InnoBiz designation for implementing the innovative activities of the SMEs should also be revised. When designating the InnoBiz firms, the CEO's academic credentials should be considered rather than the incumbent technology. Even though patent numbers by themselves do not yield anything directly related with the firm's innovation activities, they are an important indicator of the possibility of ceaseless firm growth. Overall conclusion is that innovation, no matter how it is measured, does boost regional economic growth as well as national one. This impact is sometimes elusive due to the relatively long-term character of the process. However, any regions that do not invest into research and development do not have a basis either for technology exploitations or for indigenous technology creation regardless of ecology system of industry in each country. 


\section{References}

Argyre, N., and Silverman, B. (2004). R\&D organization structure and the development of corporate technological knowledge. Strategic Management Journal, 25, 929958.

Arora, A., and Gambardella, A. (2001). Markets for Technology and their Implications for Corporate Strategy. Industrial and Corporate Change, 10(2), 419-451.

Arundel, A. and Kabla, I. (1998). What percentage of innovations are patented? Empirical estimates for European firms. Research Policy, 27(2), 127-141.

Bhagat, S., Bolton, B., and Subramanian, A. (2010). CEO Education, CEO Turnover, and Firm Performance. http://www.unh.edu/news/docs/bolton_CEOEducation.pdf

Bloom, N., and Van Reenen, J. (2002). Patents, real options and firm performance. Economic Journal, 112, C97-C116.

Bound, J., Cummins, C., Griliches, Z., Hall, B.H., and Jaffe, A.B. (1984). Who does R\&D and who patents? In: Griliches, Z. (ed.), R\&D, Patents, and Productivity. Chicago: University of Chicago Press. pp. 21-54.

Brouwer, E., and Kleinknecht, A. (1999). Innovation output, and a firm's propensity to patent: An exploration of CIS micro data. Research Policy, 28(6), 615-624.

Chabchoub, N., and Niosi, J. (2005). Explaining the propensity to patent computer soft software. Technovation, 25(9), 971-978.

Cohen, W., and Levinthal, D. (1990). Absorptive capacity: a new perspective on learning and innovation. Administrative Science Quarterly, 35, 128-152.

Cohen, W.M., Nelson, R.R. and Walsh, J.P. (2000). Protecting their intellectual Assets: Appropriability Conditions and Why U.S. Manufacturing Firms Patent (or Not). NBER Working Paper Series No. 7552. Cambridge MA: NBER (National Bureau of Economic Research).

Covin, J.G. and Slevin, D.P. (1991). A conceptual model of entrepreneurship as firm behavior. Entrepreneurship Theory and Practice, 16(1), 7-25.

Dean, T.J. and Meyer, G.D. (1996). Industry environments and new venture formations in U.S. manufacturing: a conceptual and empirical analysis of demand determinants. Journal of Business Venturing, 11(2), 107-132.

Duguet E. and Kabla, I. (1998). Appropriation Strategy and the Motivations to Use the Patent System in France: An Econometric Analysis at the Firm Level. Annales d'Economie et de Statistique, 49-50, 290-327.

Eisingerich, A.B., Rubera, G., and Seifert, M. (2009). Managing service innovation and interorganizational relationships for firm performance: to commit or diversify? Journal of Service Research, 11, 344-356.

Gartner, W.B. (1990). What are we talking about when we talk about entrepreneurship? Journal of Business Venturing, 5(1), 15-28.

Geroski, P. (1995). Innovation and Competitive Advantage. OECD Economic Department Working Paper No. 159, OECD Publishing.

Granstrand, O. (1988). Patents and Innovation - A Study of Patenting Practices and Trends in Sweden with a Brief Outlook on the US. CIM Working Paper 1988:04. Gothenburg: Department of Industrial Management and Economics, Chalmers University of Technology.

Granstrand, O. (1999). The Economics and Management of Intellectual Property. Cheltenham: Edward Elgar, Publishing. 
Griliches, Z. (1981). Market value, R\&D, and patents, Economics Letters, 7, 183-187.

Griliches, Z. (1990). Patent Statistics as Economic Indicators: A Survey. Journal of Economic Literature 28, 1661-1707.

Hall, B.H. and Ziedonis, R.H. (2001). The patent paradox revisited: an empirical study of patenting in the U.S. semiconductor industry, 1979-1995. RAND Journal of Economics, 32(1), 101-128.

Hall, B.H. (2004). Exploring the patent explosion. Journal of Technology Transfer, 30, 35-48.

Han, J.H., Lee, J.D. and Yoon, B.S. (2008). Empirical study on the network properties of innovation in cluster. Asian Journal of Technology Innovation, 16(2), 46-66.

Han, J.H., Cho, D.H., Sin, J.S., and Kim, Y.B. (2011). The Causes of Sleeping Patents and the Effect of Firms' Patent Management Activities. Journal of Korean Technology Innovation Society, 14(4), 761-790

Heger, D., and Zaby, A.K. (2012). Giving away the game?: The impact of the disclosure effect on the patenting decision. ZEW Discussion Papers 12-010.

Holgersson, M. (2012). Patent management in entrepreneurial SMEs: a literature review and an empirical study of innovation appropriation, patent propensity, and motives. R\&D Management Journal, 43(1), 21-36.

Hoffman, K., Parejo, M., Bessant, J., and Perren, L. (1998). Small firms, R\&D technology and innovation in the UK: A literature review. Technovation, 18(1), 3955.

Hsu, D., and Ziedonis, R. (2008). Patents as quality signals. Working Paper, Wharton Business School.

Kim, J.H. and Han, J.H. (2014). Differentiated Effects of Product Strategy and CEO Characteristics on Venture Firms` Growth: The Moderating Role of Organizational Life Cycle Stage. Journal of Technology Innovation, 22(1), 25-58.

Lerner, J., and Wulf, J. (2007). Innovation and Incentives: Evidence from Corporate, R\&D. Review of Economics and Statistics, 89(4), 634-644.

Levin, R.C., Klevorick, A.K., Nelson, R.R., and Winter, S.G. (1987). Appropriating the returns from industrial research and development. Brookings Papers on Economic Activity, 3, 783-820.

Mansfield, E. (1986). Patents and innovation: an empirical Study. Management Science, 32, 2, 173-181.

Marcus, H. (2012). Patent management in entrepreneurial SMEs: a literature review and an empirical study of innovation appropriation, patent propensity, and motive. $R \& D$ Management, 43(1), 21-36.

Nicholas, T. (2011). Did R\&D firms used to patent? Evidence from the first innovation surveys. The Journal of Economic History, 71(4), 1029-1056.

Lotti, F., Santarelli, E. and Vivarelli, M. (2009). Defending Gibrat's law as a long- run regularity. Small Business Economics, 32, 31- 44.

Lowe, R.A. (2001). The role and experience of start-ups in commercializing University invention. In G. Libecap (Ed.) Entrepreneurial inputs and output. Amsterdam: JAI Press.

Pavitt, K. (1982). R\&D, patenting and innovative activities: a statistical exploration. Research Policy, 11(1), 33-51.

Rassenfosse, G. (2012). How SMEs exploit their intellectual property assets: evidence from survey data. Small Business Economics, 39(2), 437-452.

Roger, M. (2004). Networks firm size and innovation. Small Business Economics, 22, 
141-153.

Scherer, F.M. (1983). The propensity to patent. International Journal of Industrial Organization, 1(1), 107-128.

Sutton, J. (1997). Gibrat’s legacy. Journal of Economic Literature, 35, 40-59.

Teece, D.J. (1986). Profiting from technological innovation: implications for integration, collaboration, licensing and public policy. Research Policy, 15, 6, 285305.

Thumm, N. (2004). Motives for patenting biotechnological inventions; an empirical investigation in Switzerland. International Journal of Technology Policy and management, 4(3), 275-285.

Williams, C. and Lee, S.H. (2009). Exploring the Internal and External Venturing of Large R\&D Intensive Firms. R\&D Management, 39(3), 231-246. 
Table 1 . The frequency distribution of the categorical variable $(n=263)$

\begin{tabular}{|c|c|c|c|c|}
\hline \multicolumn{2}{|l|}{ Variables } & \multirow{2}{*}{$\begin{array}{c}\text { Frequency } \\
151\end{array}$} & \multirow{2}{*}{$\begin{array}{c}\text { Percent } \\
\text { (\%) }\end{array}$} & \multirow{2}{*}{$\begin{array}{c}\text { Cumulative } \\
\text { Frequency } \\
151\end{array}$} \\
\hline Industry & $\begin{array}{l}\text { Industry } 1 \\
\text { (automotive and machinery) }\end{array}$ & & & \\
\hline & $\begin{array}{l}\text { Industry } 2 \\
\text { (Electronic and Electricity) }\end{array}$ & 51 & 19 & 202 \\
\hline & $\begin{array}{l}\text { Industry } 3 \\
\text { (photonic) }\end{array}$ & 61 & 23 & 263 \\
\hline \multirow[t]{2}{*}{ InnoBiz } & $\begin{array}{l}1 \text { (When a firm is InnoBiz, then } \\
1 \text {, otherwise } 0 \text { ) }\end{array}$ & 112 & 43 & 263 \\
\hline & 0 & 151 & 57 & 151 \\
\hline \multirow[t]{3}{*}{ Firm age } & $1 \sim 10$ years & 109 & 42 & 109 \\
\hline & 11 20 years & 122 & 45 & 231 \\
\hline & More than 21 & 32 & 13 & 263 \\
\hline \multirow[t]{2}{*}{ Research Division } & $\begin{array}{l}1 \text { (When a firm has research } \\
\text { division then } 1 \text {, otherwise } 0 \text { ) }\end{array}$ & 84 & 32 & 263 \\
\hline & 0 & 179 & 68 & 179 \\
\hline \multirow[t]{2}{*}{ Patents } & $1 \sim 10$ & 74 & 28 & 256 \\
\hline & More than 11 & 10 & 0.4 & 263 \\
\hline \multirow[t]{2}{*}{$\begin{array}{l}\text { CEO Academic } \\
\text { degree }\end{array}$} & Master Degree or below & 235 & 89 & 235 \\
\hline & Ph.D. Degree & 28 & 11 & 263 \\
\hline
\end{tabular}

Table 2. Summary statistics of variables and their measurement

\begin{tabular}{|c|c|c|c|c|c|}
\hline Variable & Definition of variables & Mean & $\begin{array}{c}\text { Std } \\
\text { Dev }\end{array}$ & $\begin{array}{l}\text { Mini } \\
\text { mum }\end{array}$ & $\begin{array}{l}\text { Maxi } \\
\text { mum }\end{array}$ \\
\hline Patent & $\begin{array}{l}\text { Number of patent created during } \\
\text { 3years (dependent variable) }\end{array}$ & 1.76 & 3.64 & 0.00 & 28.00 \\
\hline Res Fund & $\begin{array}{l}\text { Total research expenditure (in 1,000 } \\
\text { KW) }\end{array}$ & 54802 & 175621 & 0.00 & 141696 \\
\hline Ind Code 1 & $\begin{array}{l}\text { Automotive parts and machinery, } \\
\text { dummy }\end{array}$ & 0.25 & 0.43 & 0.00 & 1 \\
\hline Ind Code2 & $\begin{array}{l}\text { Electronic and Electricity industry, } \\
\text { dummy }\end{array}$ & 0.19 & 0.40 & 0.00 & 1 \\
\hline Ind Code3 & Photonic industry, dummy & 0.23 & 0.42 & 0.11 & 1 \\
\hline InnoBiz & $\begin{array}{l}\text { Innovative firm certificated by } \\
\text { government }\end{array}$ & 0.43 & 0.50 & 0.00 & 1 \\
\hline Firm age & $\begin{array}{l}\text { SMEs age, the number of years the } \\
\text { firm has been in existence from its } \\
\text { foundation }\end{array}$ & 12.59 & 6.07 & 2.00 & 32.00 \\
\hline Res Div & $\begin{array}{l}\text { Research division within SMEs, } \\
\text { dummy }\end{array}$ & 0.32 & 0.47 & 0.00 & 1 \\
\hline Researcher & $\begin{array}{l}\text { Number of researcher working at } \\
\text { research division }\end{array}$ & 1.59 & 3.35 & 0.00 & 21 \\
\hline CEO deg1 & $\begin{array}{l}\text { CEO graduated from under } \\
\text { university, dummy }\end{array}$ & 0.48 & 0.50 & 0.00 & 1 \\
\hline CEO deg2 & CEO has Ph.D., dummy & 0.11 & 0.31 & 0.00 & 1 \\
\hline Employees & Number of employee & 35.59 & 45.54 & 1.00 & 303 \\
\hline
\end{tabular}

Note: Other industries and high school degree are reference categories. 
Table 3. Least squares estimation results of patent propensity model, $n=263$.

\begin{tabular}{|c|c|c|c|c|c|c|c|}
\hline \multirow{3}{*}{$\begin{array}{l}\text { Dependent } \\
\text { Variable } \\
\text { Variable }\end{array}$} & \multicolumn{7}{|c|}{ Patent } \\
\hline & \multirow[b]{2}{*}{$\begin{array}{l}\text { Parameter } \\
\text { Estimate }\end{array}$} & \multirow{2}{*}{$\begin{array}{l}\text { OLS } \\
\text { Std } \\
\text { Error }\end{array}$} & \multirow[b]{2}{*}{ t-value } & \multirow[b]{2}{*}{$\operatorname{Pr}>|t|$} & \multicolumn{3}{|c|}{ Heterosc. consistent Std Errors } \\
\hline & & & & & $\begin{array}{l}\text { Std } \\
\text { Error }\end{array}$ & t-value & $\operatorname{Pr}>|t|$ \\
\hline Intercept & 1.1375 & 0.6236 & 1.82 & 0.0056 & 0.4290 & 2.65 & 0.0051 \\
\hline Ln Res fund & 0.2086 & 0.0424 & 4.91 & 0.0001 & 0.0645 & 3.24 & 0.0014 \\
\hline Ind. code1 & -1.5276 & 0.5368 & -2.85 & 0.0048 & 0.5005 & -3.05 & 0.0025 \\
\hline Ind. code2 & -1.3415 & 0.5930 & -2.26 & 0.0245 & 0.6684 & -2.01 & 0.0458 \\
\hline Ind. code3 & -0.9689 & 0.5445 & -1.78 & 0.0762 & 0.6226 & -1.56 & 0.1209 \\
\hline InnoBiz & 0.2530 & 0.4463 & 0.57 & 0.5714 & 0.4481 & 0.56 & 0.5729 \\
\hline Firm age & 0.0128 & 0.0340 & 0.38 & 0.7069 & 0.0291 & 0.44 & 0.6600 \\
\hline Res div. & -0.0732 & 0.6383 & -0.11 & 0.9088 & 0.6039 & -0.12 & 0.9037 \\
\hline Researcher & 0.2976 & 0.0849 & 3.50 & 0.0005 & 0.1150 & 2.59 & 0.0102 \\
\hline CEO deg1 & -0.1076 & 0.4292 & -0.25 & 0.8023 & 0.3653 & -0.29 & 0.7686 \\
\hline CEO deg2 & 1.8790 & 0.6989 & 2.69 & 0.0077 & 1.1389 & 1.65 & 0.1002 \\
\hline Root MSE & \multicolumn{3}{|c|}{3.2013} & & & & \\
\hline Coeff Var & \multicolumn{2}{|c|}{179.9013} & & & & & \\
\hline $\begin{array}{l}\text { F-value } \\
\text { (prob.) }\end{array}$ & \multicolumn{3}{|c|}{$8.6300(0.0001)$} & & & & \\
\hline Adj R ${ }^{2}$ & \multicolumn{3}{|c|}{0.2256} & & & & \\
\hline
\end{tabular}

Appendix A. Correlation coefficients, $(\mathrm{N}=263)$

\begin{tabular}{ccccccc}
\hline & $(1)$ & $(2)$ & $(3)$ & $(4)$ & $(5)$ & $(6)$ \\
\hline & InnoBiz & Firmage & Resdiv & Reseacher & patent & Rfund \\
\hline$(1)$ & 1.0000 & & & & & \\
& & & & & & \\
$(2)$ & 0.1915 & 1.0000 & & & & \\
& 0.0018 & & & & & \\
$(3)$ & 0.2511 & 0.0383 & 1.0000 & & & \\
& $<.0001$ & 0.5360 & & & & \\
$(4)$ & 0.0160 & 0.1348 & 0.6932 & 1.0000 & & \\
& 0.7954 & 0.0288 & $<.0001$ & & & \\
$(5)$ & 0.0713 & 0.0665 & 0.2639 & 0.3308 & 1.0000 & \\
& 0.2488 & 0.2823 & $<.0001$ & $<.0001$ & & \\
$(6)$ & 0.0606 & -0.0081 & 0.2571 & 0.1348 & 0.3811 & 1.0000 \\
& 0.3271 & 0.8950 & $<.0001$ & 0.0288 & $<.0001$ & \\
\hline
\end{tabular}

Note: Person Correlation Coefficients, $\mathrm{Pr}>|\mathrm{r}| \mathrm{H} 0$; Rho= O 